\title{
INITIATION OF VANCOMYCIN THERAPY AND THE FIRST THERAPEUTIC DRUG MONITORING
}

\author{
Inga Mauliṇa ${ }^{1,3, \#}$, Angelika Krūmina ${ }^{1,4}$, Aleksandra Aitullina ${ }^{2,4}$, Roberts Erts ${ }^{5}$, \\ Katrīna Bandere ${ }^{1}$, Dace Bandere ${ }^{4}$, and Eva Strīke 2,4 \\ ${ }^{1}$ Rīga East Clinical University Hospital, 2 Hipokrāta Str., Rīga, LV-1038, LATVIA \\ 2 Pauls Stradiṇš Clinical University Hospital, 13 Pilsoṇu Str., Rīga, LV-1002, LATVIA \\ ${ }^{3}$ Vidzeme Hospital, 195 Jumaras Str., Valmiera, LV-4201, LATVIA \\ ${ }^{4}$ Rīga Stradinš̌ University, 16 Dzirciema Str., Rīga, LV-1007, LATVIA \\ ${ }^{5}$ University of Latvia, 19 Raiṇa Blvd., Rīga, LV-1586, LATVIA \\ \# Corresponding author, ingamaulina@inbox.Iv
}

Communicated by Igors Aksiks

\begin{abstract}
There have been a limited number of studies in Latvia that were focused on vancomycin therapeutic drug monitoring (TDM), especially during the initiation phase of the therapy. The aim of this study was to investigate details of vancomycin therapy in its initiation phase and to analyse the results of the first therapeutic drug monitoring within a multidisciplinary hospital in Latvia. A retrospective observational study was performed in a multidisciplinary hospital in Latvia. Adult patients hospitalised in an intensive care unit and undergoing vancomycin therapy with at least one concentration measurement were included in this study. Data about patients included demographic and clinical data, renal function prior to initiation of vancomycin therapy, data about vancomycin therapy, data about the first TDM, and details about the first measurement of vancomycin concentration according to determined reference range - subtherapeutic, therapeutic and supratherapeutic levels. A total of 60 intensive care unit patients who received vancomycin with at least one concentration measurement were included in this study. Fifty-eight patients received vancomycin as intermittent intravenous infusion. The first measurement of concentration was taken before the $3^{\text {rd }}-4^{\text {th }}$ vancomycin dose in $38.3 \%$ cases, and in $33.3 \%$ cases - before the $2^{\text {nd }}$ dose. Sampling to determine the concentration within 30 minutes before vancomycin administration was performed in zero cases. In 35\% cases, sampling was done within 2-5 hours before vancomycin administration and in $23.3 \%$ - immediately after or within a few hours after vancomycin infusion. Twelve (20\%) patients had a concentration in the subtherapeutic level, and $14(23.3 \%)$ patients had concentrations above the therapeutic level. In $42.8 \%$ of patients who had concentrations in supratherapeutic level, sampling had been performed immediately after or within several hours after vancomycin administration. The first concentration measurement was performed more than one hour before an infusion in all cases. Data on concentrations and timing were not adequate to perform appropriate therapy modification. Interpretation of dosing regime and concentration results were not adequate, and therefore correct modification of vancomycin therapy was often not possible. Routines of correct dosing regime and the $1^{\text {st }}$ TDM during the initiation phase of vancomycin therapy can be improved.
\end{abstract}

Key words: concentration measurement, narrow therapeutic range, antibacterial agents, minimum inhibitory concentration.

\section{INTRODUCTION}

Adequate dosage and administration of vancomycin as well as monitoring of its concentration, especially at the begin- ning of vancomycin therapy, is important in treating bacterial infections.

Monitoring of vancomycin concentration in serum is a widely used practice worldwide that helps to evaluate the 
direction of vancomycin therapy and make necessary adjustments (Gould et al., 2012; Tabah et al., 2015; Bakke et al., 2017; Hanberger, 2017).

Due to many factors, reaching a therapeutic level of vancomycin is rather difficult for patients in hospitals, particularly for those in intensive care (Revilla et al., 2010). An individual approach is necessary in such cases, including therapy adjustments based on vancomycin TDM, including for patients with oral vancomycin (McDonald et al., 2018).

Vancomycin is a time-dependent antibiotic. Its administration should always be scheduled before the concentration has decreased to below the minimum inhibitory concentration (MIC) level (Rybak, 2006). Vancomycin concentration below the MIC level can result in increased risk of microbial resistance (Estes and Derendorf, 2010). It is important that sampling to determine its concentration is performed immediately before vancomycin infusion (Rybak et al., 2009; Hammond et al., 2017).

Vancomycin doses and the dosing regimen should be determined before the initiation of therapy. The severity of infection, body weight, age and renal function should be taken into consideration. Also, administration of further maintenance doses after the first loading dose are recommended (Rybak et al., 2009; Bakke et al., 2017; Hanberger, 2017, at pp. 57-161).

In case of renal impairment, elimination of vancomycin decreases and accumulation is observed (De Gatta Garcia et $a l .$, 2007). Therefore, reduced maintenance doses or longer dosing intervals are needed (Barber et al., 2016; Hanberger, 2017, at pp. 57-161). However, a contradictory tendency has been observed in obese patients (Grace, 2012) and in patients with augmented renal function (Tabah et al., 2015).

In cases of intermittent vancomycin infusion, the first TDM before the $3^{\text {rd }}$ or $4^{\text {th }}$ dose is recommended for patients with normal renal function (Rybak et al., 2009; Zamoner et al., 2019). If the vancomycin concentration is outside its therapeutic range, the therapy should be adapted accordingly (Tafelski et al., 2015).

The purpose of this study was to investigate the details of vancomycin therapy in its initiation phase and analyse the results of the first therapeutic drug monitoring within a multidisciplinary hospital in Latvia.

The target data for analysis were:

1. Initial doses and dosing regimens of vancomycin before the first TDM;

2. Results of the $1^{\text {st }}$ TDM of vancomycin;

3. Vancomycin dosing tactics in cases of abnormal vancomycin plasma concentrations.

\section{MATERIALS AND METHODS}

The retrospective observational study was performed in a multidisciplinary hospital in Latvia. Sixty patients in an in- tensive care unit (ICU) on vancomycin therapy with at least one concentration measurement were included in this study. The study was approved in Ethical Committee of Rīga Stradiņš University, approval No. 38/26.10.2017.

Data on patients were obtained from the digital database of the hospital laboratory and archived medical records. The data included vancomycin concentration measurements performed during the period of 01.12.2016-30.09.2017.

Adult patients older than 18 years of age, hospitalised in the ICU, were included in this study.

Patient data were categorised as following:

1. Demographic and clinical data: gender, age, weight, body mass index (BMI), duration of hospitalisation, mortality, creatinine clearance, Glomerular Filtration Rate (GFR).

2. Renal function prior to vancomycin therapy: patients with normal renal function GFR $\geq 60 \mathrm{~mL} / \mathrm{min} / 1.73$ $\mathrm{m}^{2}$ (augmented renal function (GFR > 130); normal renal function (GFR 60-130)); patients with impaired renal function GFR $\leq 60 \mathrm{~mL} / \mathrm{min} / 1.73 \mathrm{~m}^{2}$ (moderate impairment (Stage 3) - Stage 3a (GFR 45-59), Stage 3b (GFR 30-44)); severe renal impairment (Stage 4) (GFR 15-29); renal failure (Stage 5) $($ GFR $<15$ or dialysis)).

3. Data on vancomycin therapy: duration, cases of empirical therapy, indication, result of vancomycin concentration, administration (peroral or intravenous, continuous or intermittent, dosage regime prior to the first concentration measurement, duration of infusion).

4. Data on the first TDM and the division of TDM groups: Group 1 (the 1st TDM performed prior to the $2^{\text {nd }}$ vancomycin dose), Group 2 (the 1 st TDM performed prior to the $3^{\text {rd }}$ or $4^{\text {th }}$ dose), Group 3 (the 1 st TDM performed prior to the $5^{\text {th }}-9^{\text {th }}$ dose), Group 4 (the 1st TDM performed immediately after or several hours after the vancomycin administration).

5. Details about vancomycin concentration according to determined reference ranges: subtherapeutic, therapeutic and supratherapeutic levels, and tactics on therapy adjustment after the $1^{\text {st }}$ TDM.

Descriptive statistical method was used for data analysis. Means (M) and standard deviations (SD) were used for quantitative assessment of normally distributed data. Data which did not comply with data normalisation, median (Me) and interquartile ratio [IQR] were applied. Verification of data distribution was performed with the KolmogorovSmirnov test. For processing qualitative data, the Pearson's chi-squared statistical test was performed if the expected values in the contingency table were 5. Additionally, the Fisher's exact test was used if expected values were $<5$. 


\section{RESULTS}

Of the 60 study patients, $29(48.3 \%)$ were women and 31 $(51.7 \%)$ were men. Age was consistent with a normal distribution and $\mathrm{M}$ and SD (min-max) were 58.5 ; 12.3 (23-85) years $(p=0.20)$, respectively. The average hospitalisation length did not comply with a normal distribution; Me; [IQR] (min-max) were 27.0; [19.3] (4-66) days $(p=0.03)$. Hospitalisation of $24(40 \%)$ patients was planned before hospitalisation. The survival rate was $60 \%$ (36 patients).

Twenty $(33.3 \%)$ patients had previously available records of weight and height. Body mass in these patients was: M; $\mathrm{SD}(\min -\max )=88.75 ; 5.1(61-210) \mathrm{kg}(p=0.2)$. The mean BMI (min-max) was 30.4; $5.1(18.2-39.5) \mathrm{kg} / \mathrm{m}^{2}(p=$ $0.14)$. Four $(20 \%)$ patients were overweight, $12(60 \%)$ patients were adipose (Grade $1-9(45 \%)$ patients; Grade $2-3(15 \%)$ patients). Data on vancomycin therapy and vancomycin concentration are presented in Table 1.

Twenty-four (40\%) patients had normal renal function (including augmented renal function in $8(33.3 \%)$ cases). Moderately impaired renal function or severe renal impairment was observed in $38(60 \%)$ patients.

Fifty-eight $(96.7 \%)$ patients received vancomycin intravenously as intermittent infusion. Two (3.3\%) patients received vancomycin orally.

The Pearson's chi-square test showed a statistically significant association between normal renal function and the choice of vancomycin dose $(p=0.001)$. Patients with normal renal function in 12 cases $(20.7 \%)$ received $1000 \mathrm{mg}$ vancomycin every $12 \mathrm{~h}$. Twenty-five $(43.1 \%)$ patients with renal impairment received $1000 \mathrm{mg}$ vancomycin every $24 \mathrm{~h}$. Vancomycin dose did not exceed $2000 \mathrm{mg}$ in total.

In all intravenous vancomycin cases, it was administered at least for one or more hours of infusion. One-hour infusion was performed in $43(74.1 \%)$ cases $(16(27.6 \%)$ with normal renal function, and 27 (46.6\%) with renal impairment).

Given that the number with infusions exceeding two hours was too small, those cases were excluded in Fisher's test. In
Table 1. Justification and duration of vancomycin therapy

\begin{tabular}{lc}
\hline \multicolumn{1}{c|}{ Parameters } & Values \\
\hline Duration of vancomycin therapy, days & \\
Me; [IQR] & $8.50[10]$ \\
min-max & $2-45$ \\
Empiric vancomycin therapy, n (\%) & $42(70 \%)$ \\
Indication of vancomycin therapy, n (\%) & \\
Sepsis & $22(36.7 \%)$ \\
Pneumonia & $10(16.7 \%)$ \\
Unlocalised infection & $5(8.3 \%)$ \\
Ventriculitis & $3(5.0 \%)$ \\
Endocarditis & $3(5.0 \%)$ \\
Mediastinitis & $3(5.0 \%)$ \\
Meningitis & $3(5.0 \%)$ \\
Peritonitis & $3(5.0 \%)$ \\
Methicillin-susceptible S. aureus sepsis & $2(3.3 \%)$ \\
Methicillin-resistant $S$. aureus sepsis & $2(3.3 \%)$ \\
Cl. difficile colitis & $2(3.3 \%)$ \\
Cholecystitis & $1(1.7 \%)$ \\
Paravalvular abscess & $1(1.7 \%)$ \\
Concentration of vancomycin in serum* & \\
5-15 $\mu \mathrm{g} / \mathrm{ml} * *, \mathrm{n}(\%)$ & $57(95 \%)$ \\
15-20 $\mu \mathrm{g} / \mathrm{ml}$ (recommendations of infectologist), n $(\%)$ & $3(5 \%)$ \\
\end{tabular}

* Reference interval of vancomycin concentration required for a patient. ** Reference interval of vancomycin concentration of hospital laboratory during the study.

analysis of 1-2 h infusions, Fisher's test showed no association between the duration of infusion and renal function.

Vancomycin dosages depending on renal function prior to the first concentration sampling and the first therapeutic drug monitoring are summarised in Table 2. The first TDM was performed for all 60 patients. Concentrations for two patients with oral vancomycin were also included in processing of data of concentration measurements. However, data on these patients were excluded from the calculations specific only for patients with parenteral vancomycin.

The first concentration measurement was performed before the $3^{\text {rd }}$ or $4^{\text {th }}$ dose in $38.4 \%$ cases, and before the $2^{\text {nd }}$ vancomycin dose - in $20(33.3 \%)$ cases. The first TDM within 30 minutes or less prior to vancomycin administration was performed in zero cases. Sampling immediately after or a

Table 2. Renal function and dosage of vancomycin prior the $1^{\text {st }}$ TDM

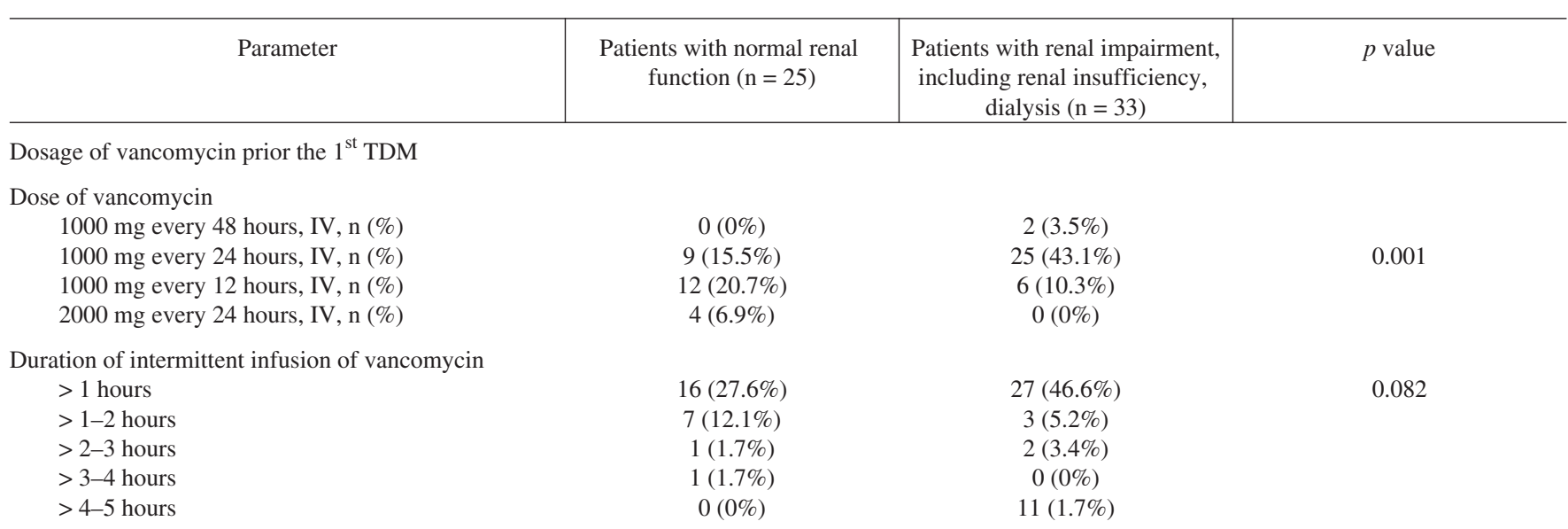


few hours after vancomycin administration was done in 14 $(23.3 \%)$ cases. The $1^{\text {st }}$ measurement before the $3^{\text {rd }}$ or $4^{\text {th }}$ doses was done for eight $(13.3 \%)$ patients with normal renal function and for $15(25 \%)$ patients with renal impairment. Concentration measurement before the $2^{\text {nd }}$ dose was performed for six $(10 \%)$ patients with normal renal function and for $14(23.3 \%)$ patients with renal impairment. The $1^{\text {st }}$ concentration measurement was performed immediately after or a few hours after vancomycin administration in 14 $(23.3 \%)$ cases, for ten patients with normal renal function and for four patients with renal impairment.

All samples performed prior to the vancomycin administration were obtained more than 1 hour (period between $13 \mathrm{~h}-1 \mathrm{~h} 11 \mathrm{~min}$ ) before vancomycin infusion. Sampling prior to the $3^{\text {rd }}$ or $4^{\text {th }}$ dose (Group 2) was taken over a period of $12 \mathrm{~h} 52 \mathrm{~min}-1 \mathrm{~h} 11 \mathrm{~min}$ prior to the vancomycin administration. Concentration measurements were taken before the $2^{\text {nd }}$ dose (Group 1) (period $13 \mathrm{~h}-1 \mathrm{~h} 42 \mathrm{~min}$ before infusion) in $20(33.3 \%)$ cases. The first concentration measurement immediately or within few hours after initiation or completion of vancomycin administration (Group 4) (interval from 5 minutes after the beginning of an infusion to $4 \mathrm{~h}$ $18 \mathrm{~min}$ after completion of administration) was done for 14 $(23.33 \%)$ patients.

The first TDM before the $2^{\text {nd }}$ dose was performed for 12 (20\%) patients with severe renal impairment (Group 1). In Group 2, eight (13.3\%) patients had GFR $\geq 60 \mathrm{ml} / \mathrm{min} / 1.73$ $\mathrm{m}^{2}$, and 25 (25\%) patients had GFR $\leq 60 \mathrm{ml} / \mathrm{min} / 1.73 \mathrm{~m}^{2}$. The Pearson's chi-square test showed a statistically significant association between normal renal function and timing (before vancomycin dose) of the $1^{\text {st }} \operatorname{TDM}(p=0.036)$. Ten $(16.67 \%)$ patients in Group 4 had GFR $\geq 60 \mathrm{ml} / \mathrm{min} / 1.73$ $\mathrm{m}^{2}$. Renal function in each TDM group is presented in Figure 1.

In Groups 1, 2 and 3 (46 (76.7\%) patients), vancomycin concentration in eight $(13.3 \%)$ cases was $<5 \mu \mathrm{g} / \mathrm{ml}$, in 28 $(46.7 \%)$ cases $5-15 \mu \mathrm{g} / \mathrm{ml}$, and in ten $(16.7 \%)$ cases $>15$ $\mu \mathrm{g} / \mathrm{ml}$. In three cases, an infectologist had recommended vancomycin concentration within $15-20 \mu \mathrm{g} / \mathrm{ml}$ as a therapeutic level, therefore one case $(10.09 \mu \mathrm{g} / \mathrm{ml})$ was classified as subtherapeutic and two cases $(16.4$ and $19 \mu \mathrm{g} / \mathrm{ml})$ as a therapeutic level. The Kolmogorov-Smirnov test showed that concentration values in each range (subtherapeutic, therapeutic, supratherapeutic) did not comply with normal- ity, and therefore the value for each range was calculated using Me; [IQR].

The first measurement of concentration in nine (15\%) cases was in the subtherapeutic range $\mathrm{M} ;[\mathrm{IQR}]-2.68$ [0.97] $\mu \mathrm{g} / \mathrm{ml}$. Two patients had GFR $\leq 60 \mathrm{~mL} / \mathrm{min} / 1.73 \mathrm{~m}^{2}$ (41 and $47 \mathrm{ml} / \mathrm{min} / 1.73 \mathrm{~m}^{2}$, respectively) (the latter patient had a recommendation of therapeutic concentration within a $15-20 \mu \mathrm{g} / \mathrm{ml}$ range). Seven patients had GFR $\geq 60$ $\mathrm{ml} / \mathrm{min} / 1.73 \mathrm{~m}^{2}$ (three patients had GFR $>130 \mathrm{ml} / \mathrm{min} / 1.72$ $\mathrm{m}^{2}$ ). In three of nine cases, concentration measurement was performed prior to the $2^{\text {nd }}$ vancomycin dose. After receiving the results of subtherapeutic concentrations, a doctor did not change the vancomycin dose nor dosing interval in four cases (all from Group 1). A doctor shortened the dosing interval in five $(8.3 \%$ ) cases (all cases in Group 2 and Group 3).

Concentration measurements for 29 (48\%) patients were within the therapeutic range $(\mathrm{M} ;[\mathrm{IQR}]=9.33$ [5.47] $\mu \mathrm{g} / \mathrm{ml})$. An infectologist had recommended a therapeutic level of $15-20 \mu \mathrm{g} / \mathrm{ml}$ for two patients. These patients were included in this category, although the vancomycin concentration was 16.04 and $19 \mu \mathrm{g} / \mathrm{ml}$, respectively. Six (10\%) patients had GFR $\geq 60 \mathrm{ml} / \mathrm{min} / 1.73 \mathrm{~m}^{2}$, and 23 (38.3\%) patients had GFR $\leq 60 \mathrm{ml} / \mathrm{min} / 1.73 \mathrm{~m}^{2}$. A doctor did not modify the dose, nor dosing interval for 17 (28.3\%) patients. The dosing interval was shortened for three patients, and there was a dose reduction for three patients.

The first concentration exceeding the upper limit of the reference interval (supratherapeutic range; above the laboratory reference $>15 \mu \mathrm{g} / \mathrm{ml}$ or recommendation by an infectologist $>20 \mu \mathrm{g} / \mathrm{ml}$ ) was observed in eight cases. The mean concentration $(\mathrm{M}$; $[\mathrm{IQR}])$ for the supratherapeutic range was $19.22 ;[5.98] \mu \mathrm{g} / \mathrm{ml}$. Sampling before the $4^{\text {th }}$ dose was performed in all cases. The vancomycin dose was reduced in one case, and in two cases the dosing interval was extended. No therapy modification was applied in five cases.

Vancomycin concentration data in TDM Groups 1, 2 and 3 are summarised in Figure 2.

In $14(23 \%)$ cases (Group 4) analysis of vancomycin concentration was taken immediately after initiation of vancomycin infusion or within a few hours after administration. Therefore, results of Group 4 were excluded from Figure 2.

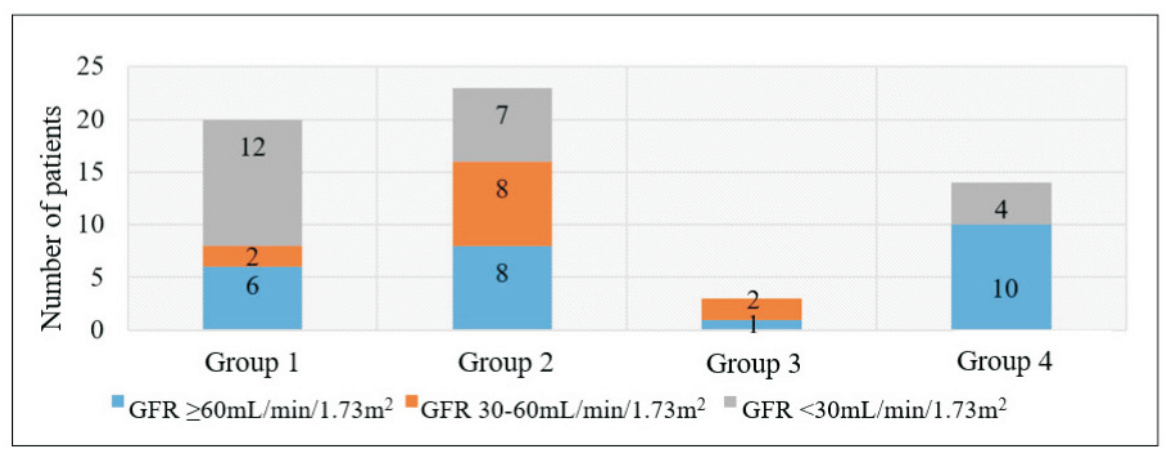

Fig. 1. Division of TDM groups and renal function. 


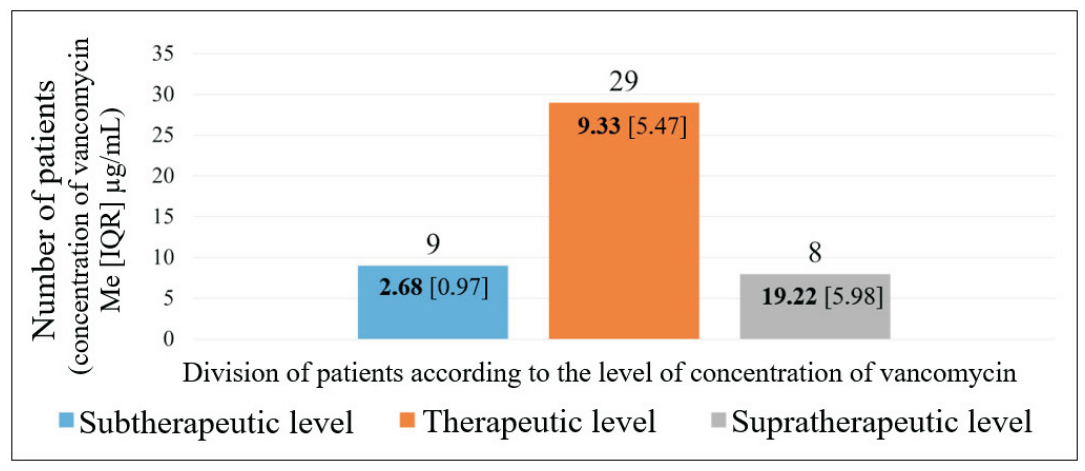

\section{DISCUSSION}

This study showed that in all cases of intravenous administration only intermittent infusions were performed. These data are consistent with other publications - in most cases vancomycin is administered as an intermittent intravenous infusion (Tabah et al., 2015). Continuous infusions are thought to be better in terms of drug safety (Hao et al., 2016), but medication incompatibilities with vancomycin should be taken into consideration (Raverdy et al., 2013).

In this study, in all cases vancomycin was administered for at least one-hour long infusion. This is a good approach in order to reduce potential risks of vancomycin side effects (Bauer, 2008, at pp. 207-298; Rybak et al., 2009). Also, in this study, vancomycin was administered as an infusion over several hours. However, more research is required to define the benefits of such prolonged intermittent infusion schemes.

It was not possible to assess the general strategy of the $1^{\text {st }}$ vancomycin dose - whether it was a maintenance dose or a loading dose. The same refers to the strength of the $1^{\text {st }}$ dose. Usually a loading dose is recommended for initiation of vancomycin therapy. The purpose of such a strategy is to reach the necessary therapeutic concentration earlier (Rybak et al., 2009; Bakke et al., 2017; Hanberger, 2017, at pp. 57-161; Ye et al., 2016).

Only $33.3 \%$ of patients in this study had available records of weight and height in medical documentation. The absence of these data creates an obstacle in utilising the loading dose, as it is usually calculated based on body weight not taking into consideration renal function in most of the cases (Tafelski et al., 2015). In literature, the recommended loading dose of vancomycin is $25-30 \mathrm{mg} / \mathrm{kg}$ (Álvarez et al., 2016; Hanberger, 2017, at pp. 57-161). Following the loading dose, therapy is usually continued with a maintenance dose $15-20 \mathrm{mg} / \mathrm{kg}$ two or three times a day (Hanberger, 2017, at pp. 57-161). Therefore, correct dosing calculations during the initial phase of vancomycin therapy would have been possible only for patients having records of weight and height.

More than a half $(60 \%)$ of the patients with weight and height measurements had Grade 1 or 2 adiposity. Achieving the appropriate vancomycin concentration and maintaining it within the therapeutic range is highly important especially for adipose patients (Grace, 2012), (Álvarez et al., 2016; Kane and Hanes, 2017). Also, low concentrations of vancomycin are associated with selection of partially or fully resistant strains (Rybak et al., 2009; Marquis et al., 2015). In contrast, excess vancomycin accumulation in renal impairment may cause toxicity (Del Mar Fernandez De Gatta Garcia et al., 2007).

TDM for patients with normal or partially impaired renal function immediately before the vancomycin infusion is the most practical method for monitoring vancomycin therapy. Sampling should be performed before the $3^{\text {rd }}$ or $4^{\text {th }}$ vancomycin dose (Rybak et al., 2009; Tafelski et al., 2015; Zamoner et al., 2019). In our study, the first TDM was performed before the $3^{\text {rd }}-4^{\text {th }}$ dose in $38.3 \%$ cases. The first TDM was performed before the $2^{\text {nd }}$ dose in $33.3 \%$ cases, which might be too early. A sufficient time is required for vancomycin to reach a steady-state concentration (Martin, 2010). Such an approach might have been applied to identify early problems of renal function. Furthermore, results from similar studies have been shown to be reported erroneously. This would cause problems in correct vancomycin therapy modification. A Norwegian study indicated that $70-80 \%$ of concentration results failed to reach therapeutic concentrations during the first three days of therapy (Bakke et al., 2017). This is a significantly higher incidence rate than in our study. Incorrect levels of concentration may be associated with inappropriate timing of concentration sampling prior to vancomycin infusion (Traugott et al., 2011).

Too early sampling prior to the infusion can result in misinterpretation of TDM results, leading to incorrect adjustment of vancomycin therapy (Morrison et al., 2018). Therefore, it is important that sampling is done right before the administration of vancomycin (within 30 minutes, max 60 minutes, before scheduled vancomycin administration) (Morrison $e t$ al., 2018). Another retrospective study was conducted in Brigham and Women's Hospital, Boston (Morrison et al., 2018). The study group discovered that in $41.3 \%$ of cases, sampling was performed too early (Morrison et al., 2018). A similar outcome was confirmed in this study. TDM was done too early and none of concentration measurements were obtained within 30 minutes or within 1 hour prior to vancomycin administration.

At the time of this study, the vancomycin reference range in the hospital laboratory was $5-15 \mu \mathrm{g} / \mathrm{ml}$. Interpretation of the concentration levels in this study was made in accordance 
with the reference standards of the laboratory. Also, there were three patients in our study with infectologist's recommendations. For those patients, a therapeutic reference interval was defined as $15-20 \mu \mathrm{g} / \mathrm{ml}$. As a result, only $20 \%$ of patients in this study had subtherapeutic concentrations. The lowest vancomycin concentration in publications is recommended as $10 \mu \mathrm{g} / \mathrm{ml}$, and a therapeutic concentration of vancomycin as 15-20 $\mu \mathrm{g} / \mathrm{ml}$ (Rybak et al., 2009; Bakke et al., 2017; Tong et al., 2020). If reference intervals of the hospital laboratory were more harmonised, the results would have likely been similar to those of Bakke et al. (Bakke et al., 2017). In this study the Me [IQR] concentration in the therapeutic range, was $9.33[5.47] \mu \mathrm{g} / \mathrm{ml}$. This indicates that concentrations often were too low and raising concern that concentrations $\mu \mathrm{g} / \mathrm{ml}$ could lead to increased resistance (Bakke et al., 2017).

$10 \%$ of patients had augmented renal function with GFR $130 \mathrm{ml} / \mathrm{min} / 1.73 \mathrm{~m}^{2}$. These patients have much higher risk of vancomycin being in subtherapeutic concentrations (Baptista et al., 2012). Results of this study correlate with other publications where patients with augmented renal function also had lower vancomycin concentrations (Dolton et al., 2010; Bakke et al., 2017; Morbitzer et al., 2016; Campassi et al., 2014).

After receiving the results of subtherapeutic concentrations, dose adjustments were made in five cases while the therapy was not changed in four cases. In one case, the first TDM was performed only before the $5^{\text {th }}$ dose. If the blood sample would have been taken earlier, subtherapeutic concentrations would have been detected and therapy adjustments performed sooner.

In $23.3 \%$ of all cases concentrations exceeded therapeutic concentrations and in $42.8 \%$ of these cases sampling was performed either immediately or within few hours after vancomycin infusion. In fact, concentration levels in such cases would be more preferably defined as the maximum (close to maximum) level. For patients with severe renal impairment or renal insufficiency, administration of continuous infusion could be considered in order to decrease nephrotoxicity risk (Jeffres, 2017). However, a previous study did not indicate an association between continuous infusion and a lower risk of nephrotoxicity (Sokolova and Sabelnikovs, 2013). New approaches, such as the AUC (Area Under the Curve) / MIC ratio could be considered for more precise vancomycin therapy (Aljefri et al., 2019; Holmes, 2020; Rybak et al., 2020).

In this study, the dosing interval was shortened for $56 \%$ of patients with subtherapeutic concentrations, and prolonged dosing intervals were applied for $37 \%$ of patients with supratherapeutic concentrations. No therapy adjustments were made for the remaining cases, despite inappropriate concentrations.

\section{CONCLUSION}

1. First doses and dosing regimens of vancomycin might not have been adjusted correctly in most of the cases.
2. The $1^{\text {st }}$ TDM before the $3^{\text {rd }}-4^{\text {th }}$ dose was performed in a low number of cases. The $1^{\text {st }}$ TDM was done too early and none of the concentration measurement were obtained within the suggested time frame in literature prior to vancomycin administration. In almost half of the cases, the vancomycin concentration was in the therapeutic level. However, since the reference range of vancomycin in the laboratory was $5-15 \mu \mathrm{g} / \mathrm{ml}$ at the time of this study the therapeutic level practically would not have been reached. The median concentration results confirm these concerns.

3. The strategy of vancomycin dosing after the $1^{\text {st }}$ TDM if outside therapeutic concentrations was often inconsistent and could be improved.

\section{REFERENCES}

Aljefri, D. M., Avedissian, S. N., Rhodes, N. J., Postelnick, M. J., Nguyen, K., Scheetz, M. H. (2019). Vancomycin area under the curve and acute kidney injury: A meta-analysis. Clin. Infect. Diseas., 69 (11), 1881-1888.

Álvarez, R., Cortes, L. E. L., Molina, J., Cisneros, J. M., Pachón, J. (2016) Optimizing the clinical use of vancomycin. Antimicrob. Agents Chemother., 60 (5), 2601-2609.

Bakke, V., Sporsem, H., Lippe, E., Nordøy, I., Lao, Y., Nyrerød, H. C., Sandvik, L., Hårvig, K. R. (2017). Vancomycin levels are frequently subtherapeutic in critically ill patients: A prospective observational study. Acta Anaesthesiol. Scand., 61 (6), 627-635.

Baptista, J. P., Sousa, E., Martins, P. J., Pimentel, J. M. (2012). Augmented renal clearance in septic patients and implications for vancomycin optimisation. Int. J. Antimicrob. Agents, 39 (5), 420-423.

Barber, K. E., Bell, A. M., Stover, K. R., Wagner, J. L. (2016). Intravenous vancomycin dosing in the elderly: A focus on clinical issues and practical application. Drugs and Aging, 33 (12), 845-854.

Bauer, L. A. (2008). Applied Clinical Pharmacokinetics. $2^{\text {nd }}$ ed. The McGraw-Hill Companies, Inc. 826 pp.

Campassi, M. L., Gonzalez, M. C., Masevicius, F. D., Vazquez, A. R., Moseinco, M., Navarro, N. C., Previgliano, L., Rubatto, N. P., Benites, M. H., Estenssoro, E., Dubin, A. (2014). Augmented renal clearance in critically ill patients: Incidence, associated factors and effects on vancomycin treatment. Revista Brasileira de Terapia Intensiva, 26 (1), 13-20 (in Portuguese).

Dolton, M., Xu, H., Cheong, E., Maitz, P., Kennedy, P., Gottlieb, T., Buono, E., McLachlan, A. J. (2010). Vancomycin pharmacokinetics in patients with severe burn injuries. Burns, 36 (4), 469-476.

Estes, K. S., Derendorf, H. (2010). Comparison of the pharmacokinetic properties of vancomycin, linezolid, tigecyclin, and daptomycin. Eur. J. Med. Res., 15 (12), 533.

Gould, F. K., Denning, D. W., Elliott, T. S., Foweraker, J., Perry, J. D., Prendergast, B. D., Sandoe, J. A. T., Spry, M. J., Watkin, R. W., Working Party of the British Society for Antimicrobial Chemotherapy (2012). Guidelines for the diagnosis and antibiotic treatment of endocarditis in adults: A report of the Working Party of the British Society for Antimicrobial Chemotherapy. J. Antimicrob. Chemother., 67 (2), 269-289.

Grace, E. (2012). Altered vancomycin pharmacokinetics in obese and morbidly obese patients: What we have learned over the past 30 years. $J$. Antimicrob. Chemother., 67 (6), 1305-1310.

Hammond, D. A., Atkinson, L. N., James, T. B., Painter, J. T., Lusardi, K. (2017). Effects of staff education and standardizing dosing and collection times on vancomycin trough appropriateness in ward patients. Pharmacy Practice, 15 (2), 1-5.

Hanberger, R. H. (2017). SEPSIS in Emergency \& ICU. 3 rev. ed. LiU-Tryck, Universitetet i Linköping, Linköping. 166 pp. (in Swedish). 
Hao, J. J., Chen, H., Zhou, J. X. (2016). Continuous versus intermittent infusion of vancomycin in adult patients: A systematic review and meta-analysis. Int. J. Antimicrob. Agents, 47 (1), 28-35.

Holmes, N. E. (2020). Using AUC/MIC to guide vancomycin dosing: Ready for prime time? Clin. Microbiol. Infect., 26 (4), 406-408.

Jeffres, M. N. (2017).The whole price of vancomycin: Toxicities, troughs, and time. Drugs, 77 (11), 1143-1154.

Kane, S. P., Hanes, S. D. (2017). Unexplained increases in serum vancomycin concentration in a morbidly obese patient. Intens. Crit. Care Nursing, 39, 55-58.

De Gatta Garcia, M. Del Mar F., M., Revilla, N., Calvo, M. V., Dominguez-Gil, A., Navarro, A. S. (2007). Pharmacokinetic/pharmacodynamic analysis of vancomycin in ICU patients. Intens. Care Med., 33 (2), 279-285

Marquis, K. A., DeGrado, J. R., Labonville, S., Kubiak, D. W., Szumita, P. M. (2015). Evaluation of a pharmacist-directed vancomycin dosing and monitoring pilot program at a tertiary academic medical center. Ann. Pharmacother., 49 (9), 1009-1014.

Martin, J. (2010). TDM for vancomycin-induced nephrotoxicity definition: A minimum of two or three consecutive. Clin. Biochem. Rev., 22, 21-24.

McDonald, L. C., Gerding, D. N., Johnson, S., Bakken, J. S., Carroll, K. C., Coffin, S. E., Dubberke E. R., Garey, K. W., Gould, C. V., Kelly, C., Loo, V., Sammons, J. S., Sandora, T. J., Wilcox, M. H. (2018). Clinical Practice Guidelines for Clostridium difficile Infection in Adults and Children: 2017 Update by the Infectious Diseases Society of America (IDSA) and Society for Healthcare Epidemiology of America (SHEA). Clin. Infect. Dis., 66 (7), $\mathrm{e} 1-\mathrm{e} 48$.

Morbitzer, K. A., Jordan, J. D., Sullivan, K. A., Durr, E. A., Olm-Shipman, C. M., Rhoney, D. H. (2016). Vancomycin pharmacokinetic parameters in patients with hemorrhagic stroke. Neurocrit. Care, 25 (2), 250-257.

Morrison, A. P., Morrison, A. P., Melanson, S. E. F., Carty, M. G., Bates, D. W., Szumita, P. M., Tanasijevic, M. J. (2018). What proportion of vancomycin trough Levels are drawn too early? Frequency and impact on clinical actions. Amer. J. Clin. Pathol., 137 (3), 472-478.

Raverdy, V., Ampe, E., Hecq, J.-D., Tulkens, P. M. (2013). Stability and compatibility of vancomycin for administration by continuous infusion. $J$. Antimicrob. Chemother., 68 (5), 1179-1182.

Revilla, N., Martín-Suárez, A., Pérez, M. P., González, F. M., Fernández de Gatta, M. (2010). Vancomycin dosing assessment in intensive care unit patients based on a population pharmacokinetic/pharmacodynamic simulation. Brit. J. Clin. Pharmacol., 70 (2), 201-212.
Rybak, M., Lomestro, B., Rotschafer, J. C., Moellerinmg, Jr., R., Craig, W., Billeter, M., Dalovisio, J. R., Levine, D. P. (2009). Therapeutic monitoring of vancomycin in adult patients: A consensus review of the American Society of Health-System Pharmacists, the Infectious Diseases Society of America, and the Society of Infectious Diseases Pharmacists. Amer. J. Health-System Pharm., 66 (1), 82-98.

Rybak, M. J. (2006). The pharmacokinetic and pharmacodynamic properties of vancomycin. Clin. Infect. Dis., 42 (Suppl. 1), S35-S39.

Rybak, M. J., Le, J., Lodise, T. P., Levine, D. P., Bradley, J. S., Liu, C., Mueller, B. A., Pai, M. P., Wong-Beringer, A., Rotschafer, J. C., Rodvold, K. A., Maples, H. D., Lomaestro, B. M. (2020).Therapeutic monitoring of vancomycin for serious methicillin-resistant Staphylococcus aureus infections: A revised consensus guideline and review by the American Society of Health-System Pharmacists, the Infectious Diseases Society of America, the Pediatric Infectious Diseases Society, and the Society of Infectious Diseases Pharmacists. Amer. J. Health-System Pharm., 77 (11), 835-863.

Sokolova, V., Sabelnikovs, O. (2013). Effect of vancomycin administration method on achieving and maintaining its serum concentrations in intensive care patients. Acta Chirurgica Latviensis, 13 (1), 18-21.

Tabah, A., Waele, J. de, Lipman, J., Zahar, J. R., Cotta, M. O., Barton, G., Timsit, J.-F., Roberts, J. A., Working Group for Antimicrobial Use in the ICU within the Infection Section of the European Society of Intensive Care Medicine (ESICM) (2015). The ADMIN-ICU survey: A survey on antimicrobial dosing and monitoring in ICUs. J. Antimicrob. Chemother., 70 (9), 2671-2677.

Tafelski, S., Nachtigall, I., Troeger, U., Deja, M., Krannich, A., Günzel, K., Spies, C., ABx Study Group (2015) Observational clinical study on the effects of different dosing regimens on vancomycin target levels in critically ill patients: Continuous versus intermittent application. J. Infect. Publ. Health, 8 (4), 355-363.

Tong, S. Y. C., Lye, D. C., Yahav, D., Sud, A., Robinson, J. O., Nelson, J., Archuleta, S., Roberts, M. A., Cass, A., Paterson, D. L. et al. (2020). Effect of vancomycin or daptomycin with vs without an antistaphylococcal $\beta$-lactam on mortality, bacteremia, relapse, or treatment failure in patients with MRSA bacteremia: A randomized clinical trial. J. Amer. Med. Assoc., 323 (6), 527-537.

Traugott, K. A., Maxwell, P. R., Green, K., Frei, C., Lewis, J. S. $2^{\text {nd }}(2011)$. Effects of therapeutic drug monitoring criteria in a computerized prescriber-order-entry system on the appropriateness of vancomycin level orders. Amer. J. Health-System Pharm., 68 (4), 347-352.

Zamoner, W., Prado, I. R. S., Balbi, A. L., Ponce, D. (2019). Vancomycin dosing, monitoring and toxicity: Critical review of the clinical practice. Clin. Exper. Pharmacol. Physiol., 46 (4), 292-301.

Received 27 July 2020

Accepted in the final form 13 January 2021

\section{VANKOMICĪNA TERAPIJAS UZSĀKŠANA UN PIRMREIZĒJAIS TERAPEITISKAIS ZĀḶU MONITORINGS}

Dati par antibakteriālo līdzekḷu terapijas pielāgošanas niansēm Latvijā, pamatojoties uz terapeitisko zāḷ monitoringu (TZM), īpaši terapijas sākumā, ir pieejami nelielā daudzumā. Pētījuma mērḳis bija noskaidrot vankomicīna terapijas uzsākšanas nianses un analizēt pirmreizējā terapeitiskā zālu monitoringa rezultātus daudzprofila slimnīcā Latvijā. Retrospektīvs novērojuma pētījums tika veikts vienā no daudzprofila slimnīcām Latvijā. Pētījumā tika iekḷauti pacienti, kuri hopitalizēti intensīvās terapijas nodạ̣ā un kuriem uzsākta vankomicīna terapija ar vismaz vienu veiktu vankomicīna koncentrācijas mērījumu serumā. Pētījumā par pacientiem tika ievākti šādi dati: demogrāfiskie un klīniskie dati; nieru funkcijas rādìtāji pirms vankomicīna terapijas uzsākšanas; dati par vankomicīna terapijas niansēm, pirmreizējo TZM (terapeitisko zāḷu monitoringu), koncentrāciju mērījumu atbilstību subterapeitiskajam, terapeitiskajam vai supraterapeitiskajam līmenim. Pētîjumā tika iekḷauti 60 pacienti, kuri bija stacionēti intensīvās terapijas nodạ̣ā. 70\% pacientu vankomicīna terapija bija uzsākta empīriski. 58 pacientiem medikaments ievadìts intermitējošas, vismaz vienu stundu ilgas, intravenozas infūzijas veidā. 38,3\% pacientiem pirmais vankomicīna koncentrācijas mērījums tika veikts pirms 3.-4. devas, 33,3\% pacientiem — pirms 2 . vankomicīna devas. Nevienam no pacientiem koncentrācijas analīze netika panemta 30 minūšu laikā pirms vankomicīna ievadīšanas. 21 (35\%) pacientam koncentrācijas mērījums bija veikts 5-2 h līdz vankomicīna ievadīšanas sākumam. 23,3\% gadījumos koncentrācijas analīze tika paṇemta uzreiz vai dažu stundu laikā pēc vankomicīna ievadīšanas. 12 (20\%) pacientiem pirmajā mērījumā vankomicīna koncentrācija bija subterapeitiskajā līmenī. $14(23,3 \%)$ pacientiem koncentrācija pārsniedza terapeitisko koncentrāciju - 42,8\% gadījumos deva tika paṇemta uzreiz vai dažu stundu laikā pēc vankomicīna infūzijas. Pirmreizējā asins analīze visos gadījumos tika paṇemta vairāk nekā vienu stundu pirms vankomicīna ievadī̌sanas. Analī̌̌u rezultāti nav pietiekami pareizi interpretējami, lai varētu veikt atbilstošu vankomicīna terapijas pielāgošanu. 